\title{
Socio-Economic and Environmental Values of Acacia-Commiphora (Small-Leaved Deciduous) Forest in Ethiopia
}

\author{
Tadeyos Mesfin Israel Petros Menbere \\ Department of Biology, College of Natural and Computational Sciences, Dilla University, Dilla, Ethiopia
}

\begin{abstract}
Acacia-Commiphora is mainly found in the Southern and Central Rift Valley low lying areas with altitudes between 1000-1900m a.s.l in Ethiopia. The forest includes drought tolerant small-leaved trees and shrubs that are characteristic plant species in this group. Although the benefits of this forest for communities in Ethiopia are diverse, their socioeconomic and environmental values have not been discussed adequately. Moreover, they are facing different anthropogenic challenges associated with population growth and increased resource demand by communities. As a result, studying the forest and its value helps to promote their contribution to humans and enhance conservation measure in different parts of the country. Hence, this study was made to review the socioeconomic and environmental values of the forest and identify challenges of Acacia-Commiphora conservation in Ethiopia. These issues were addressed through exploration of different studies conducted on Acacia species and by referring various journals. According to this study, Acacia-Commiphora forest provides various benefits to the community. These forests are rich sources of gum and resin and are the main livelihood opportunities in Dryland parts of Ethiopia. Similarly, they contribute for energy source, production of home tools and protection, contribution to livestock production, income diversification, provision of medicinal values, importance in the production of industrial materials and products, etc. In addition, they provide environmental benefits including acting as habitat and food source for organisms, role in climate modulation, improve soil fertility and erosion control and enhancing biological nitrogen fixation. Despite the growing importance of the AcaciaCommiphora forests in Ethiopia, they are under threats due to various challenges. These challenges include bush encroachment and invasion of alien species, demographic pressure, competing land uses, climatic variability and climate change, food insecurity, land degradation and police related problems.
\end{abstract}

Keywords: Socio-economic, environmental, Acacia-Commiphora, Forest, Ethiopia.

DOI: $10.7176 / \mathrm{JBAH} / 10-23-02$

Publication date: December $31^{\text {st }} 2020$

DOI: $10.7176 / \mathrm{JBAH} / 10-23-02$

Publication date: December $31^{\text {st }} 2020$

\section{Introduction}

Ethiopia is known for its diverse forest resources comprising tropical rain and cloud forests in Southwest, dry forest complexity in North, South and central mountains and desert scrubs in the East and North eastern parts of the country (Lemenih and Woldemariam, 2010). Dry forests that are commonly found on the mountains and in drylands of Ethiopia make the largest portion of Ethiopian forest covering about 55 million ha (WBISPP, 2004). Dominant dry forest types of the country include Acacia-Commiphora narrow-leaved deciduous forest, lowland bamboo and combretum-Terminalia broad-leaved deciduous forests.

Dry forests are defined differently depending on their structural complexity (i.e. height and density), foliar aspects such as small-leaved versus broad-leaved, canopy cover or nature of understory vegetation and ecological attributes such as dry forests of more arid environments (eutrophic woodlands) versus woodland of relatively wetter environments (dystrophic woodlands) (FAO, 2005). In Ethiopia, the categorization of woodland vegetation overlaps with the classification based on ecological attributes such as eutrophic and dystrophic woodlands. AcaciaCommiphora small-leaved deciduous woodlands and Combretum-Terminalia broad-leaved deciduous woodlands are the two broad classes of woodlands in the country. Acacia-Commiphora which comprises eutrophic woodlands is mainly dominated by the family Fabaceae (i.e. Acacia species) and/or Burseraceae (i.e. commiphora species). They are predominantly found in the Southern, central (Rift Valley) and Eastern lowlands of the country at altitudes between 1000-1900m a.s.l. Plant species characteristic of this vegetation type are drought-tolerant smallleaved trees and shrubs, such as Acacia tortilis, A. seyal, A. senegal, A. nilotica, A. sieberiana, A. mellifera, A. drepanolobium, Commiphora africana, C. myrrha, C. fluviflora, C. habessinica, C. paolii, C. crenulata, $C$. boranensis, C. guidotti, C. erythraea, C. schimperi, C. ogadensis, C. rostrata, C. serrulata, C. gileadensis, $C$. hildebrandtii, C. erosa, C. cyclophylla, C. corrugate, B. microphylla, B. ogadensis, B. neglecta, B. rivae, Balanites aegyptiaca Maytenus senegalensis (Fig 1). Presence of succulents, occurrence of thorny species, absence of any well-developed litter layer and occurrence of tree species with relatively small leaves are the distinguishing attributes of eutrophic woodlands (FAO, 2005). 
Studies on dry forests focus on particular species and mostly are not comprehensive. This AcaciaCommiphora (small leaved deciduous) dryland forest dominated by Commiphora and Boswellia species are crucial for gum and resin production particularly in the southeastern and northeastern parts of Ethiopia (Lemenih and Woldemariam, 2010). Hence, this paper aimed to review the socioeconomic and environmental values of eutrophic woodlands (i.e. Acacia-Commiphora forest) in Ethiopia. It gives details on the socio-economic and environmental values, challenges faced by this forest type, and finally forwards suggestions for improved future management and sustainable utilization of Acacia Commiphora forest in Ethiopia.
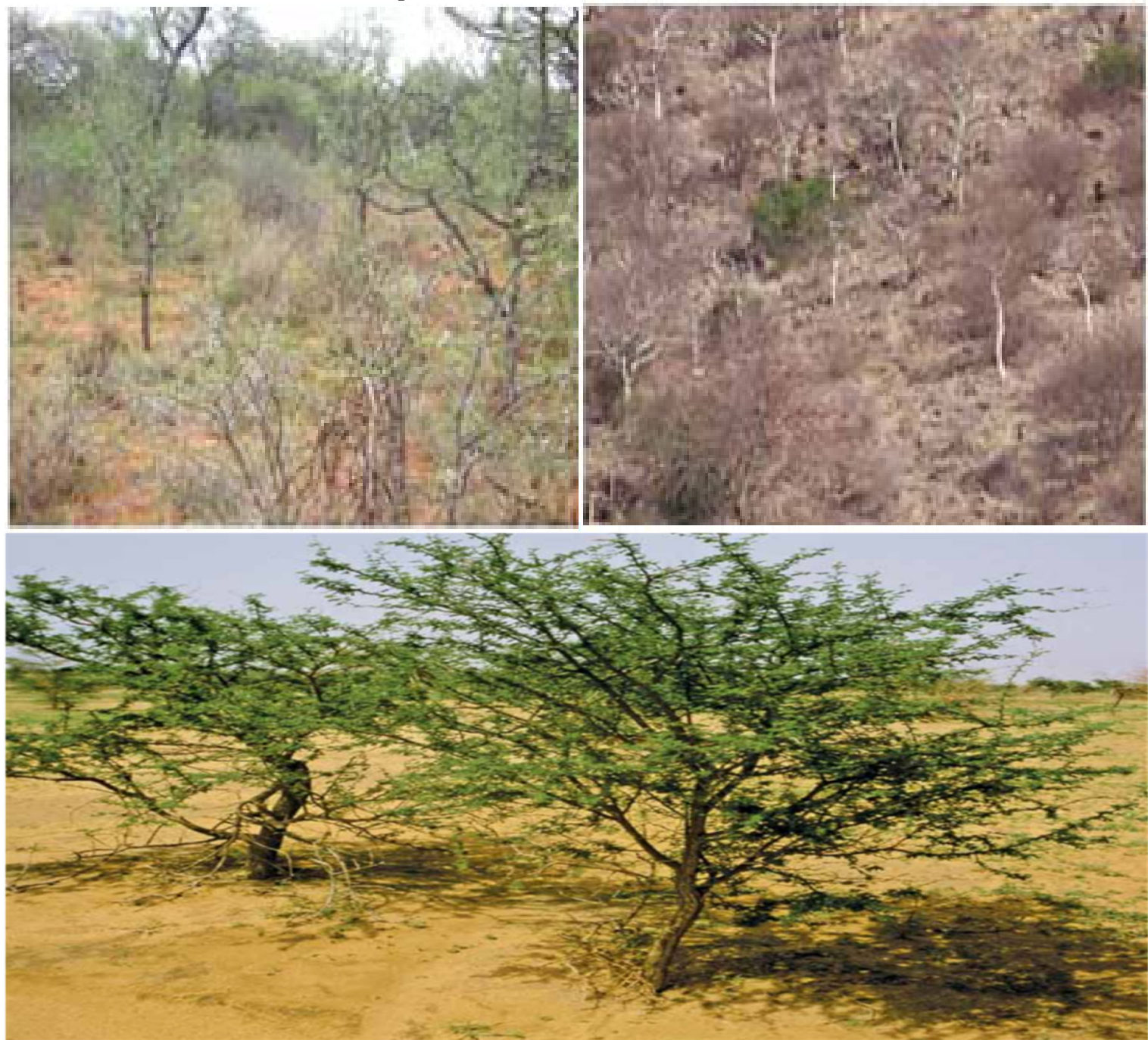

Figure 1. Acacia species

\section{Socioeconomic Values of Acacia-Commiphora Forests}

Acacia forest as source of energy

Acacia forests are valuable sources of energy in home use activities. As the majority of Ethiopians depend on fuel wood for their local energy needs, the role of Acacia as energy component is intense and especially high in lowland areas of the country. In addition, Acacia is essential in the production of charcoal and the hard wood is used to meet the energy demand in home use activities (Lemenih et al., 2003).

\section{Importance of Acacia in the production of home tools and protection}

Acacia is an important wood in the production of different homemade commodities and materials. For instance, it is used for various local purposes like making (i.e. hoe and ax handles, for house construction) and in the production exquisite furniture. Moreover, the spiny branches of African Acacias are often used for fencing homesteads, backyards or even farmlands to prevent the entrance of domestic and wild animals to agricultural land, thus minimize crop losses (Lemenih et al.,2003; Worku, 2006). 


\section{Contribution to livestock production}

As it is known, lowland Acacia dominated lands are inhabited mostly by nomadic and agro-pastoral communities. These people utilize deciduous forest resources including the perennial trees/shrubs for their livestock feed. Similarly, livestock production which is the mainstay of the agro-pastoral and pastoral economy is heavily dependent on fodder supplied from the woody plant biomass (Kuchar, 1995). This is particularly the case during the dry season and in time of droughts. The families of Burseraceae and Fabaceae (subfamily Mimosoideae) are known for their provision of nutritious fodder, and virtually all plants in the two families are palatable to livestock (Kuchar, 1988; Farah, 1994). Unlike annual grasses, perennial woody vegetation supply more fodder during prolonged drought periods, which makes them more useful in dryland regions.

\section{Income diversification}

Narrow-leaved deciduous forest support local economy through collecting and selling the plants as fuel wood, producing charcoal, and production of gum and resin from these plants. Major gum and resin products produced from the Acacia-Commiphora forests for commercial purpose in Ethiopia include gum Arabic, frankincense/olibanum, myrrh and opoponax. (Fig 2). Gum Arabic is obtained from two Acacia-Commiphora narrow-leaved deciduous forests species, namely, Acacia Senegal and Acacia seyal while Frankincense/olibanum is a gum resin tapped from several species of the genus Boswellia, and typically the Ogaden and Borana type frankincense are obtained from Acacia-Commiphora forests. In addition, myrrh, opoponax and myrrh-like gum resins are mainly concentrated in the Acacia-Commiphora forests and are products of commiphora species. As a result, Gum and resin products are important sources of livelihood and income for households residing in potential production areas (Worku, 2006). According to the study by (Lemenih et al., 2003), income from collection and sale of oleo-gum resin was the second most important means of household livelihood in Liban area, southeastern lowlands of Ethiopia. Beside the role in local livelihood and household income, gum and resin are crucial in export market to obtain foreign currency for the country (Table 1). For instance, between 1998 and 2007 about 25,192 tons, approximately 2,519 tons per year of natural gum and resin were exported from Ethiopia. This was worth ETB 307,248,000 (USD 34,138,670). This directly and indirectly benefits the local communities in producing areas by involving in the collection and production of gum and resign in different parts of the country (Lemenih and Kassa, 2008).
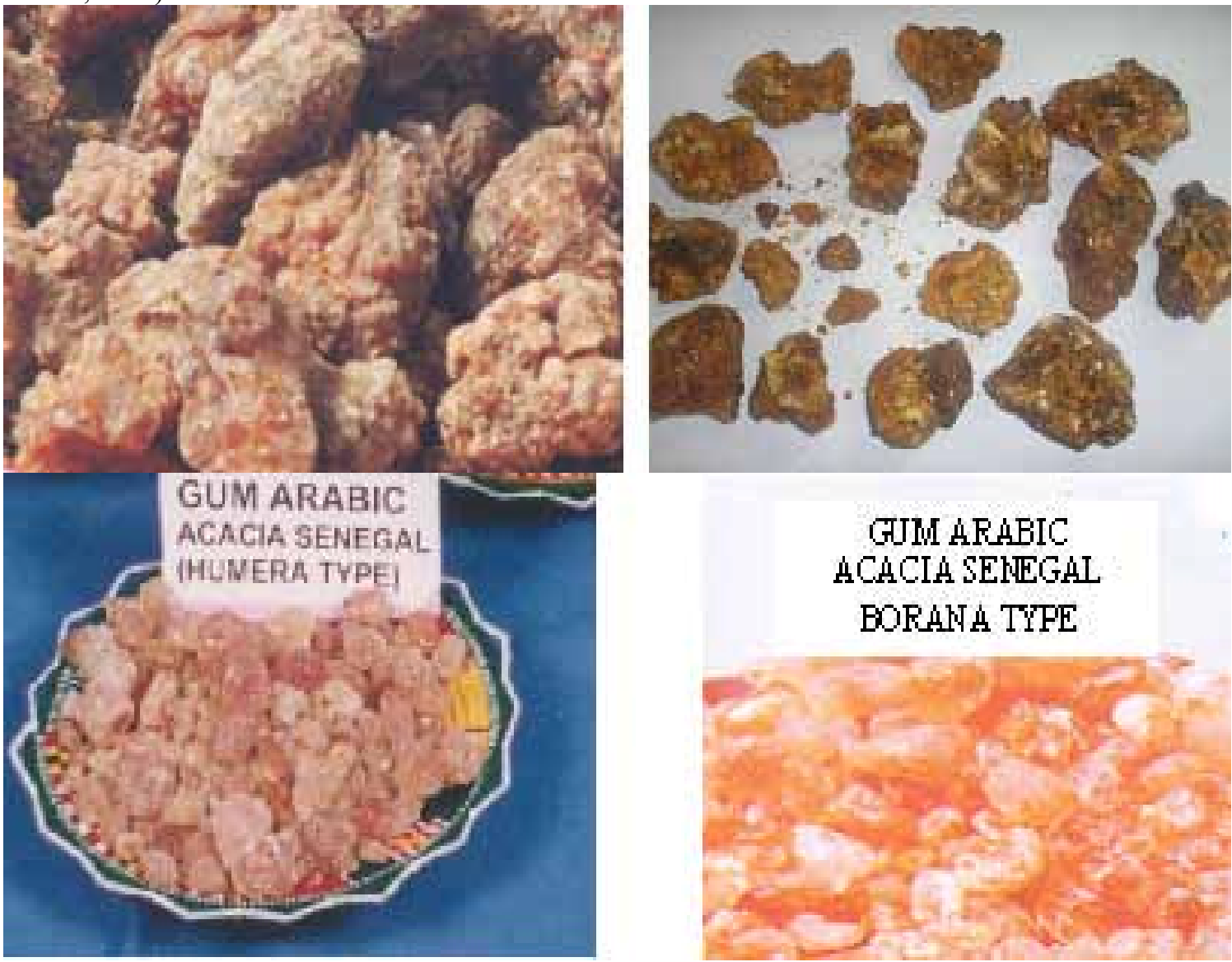

\section{GJM AFABIC ACACIA SELEGAL EORAHÁ TYFE}

Figure 2. Gum and resins produced in Ethiopia 
Table 1. Amount of natural gum export from Ethiopia and its value

\begin{tabular}{llc}
\hline Year & Quantity & Value (USD) \\
\hline 1999 & 1,594 & $2,134,389,6$ \\
2000 & 2,079 & $2,807,408,8$ \\
2001 & 2,209 & $2,771,111,9$ \\
2002 & 2,377 & $2,046,930,3$ \\
2003 & 2,720 & $4,128,165,3$ \\
\hline
\end{tabular}

Source: Demel and Mulugeta (2005).

\section{Medicinal values of Acacia species}

Due to the existence of different chemicals on the leaves and their different chemical attributes, Acacia species have medicinal values. For instance, favanoids and catechins chemicals obtained from the heartwood of $A$. Karroo and $A$. polyacantha are useful in the control of blood pressure and other human diseases. Catechins are polyphenol flavonoids, and are powerful antioxidants and useful in fighting tumors as well as boosting the immune system (Thulin and Claeson, 1991). The catechin in green tea prevents viruses from adhering and causing harm. Catechins reacts with toxins (many of which are proteins) created by harmful bacteria and harmful metals such as lead, mercury, chrome, and cadmium (Lemenih and Teketay, 2003). As acacia plants comprise useful chemicals to treat aliments of humans, they are remarkable group of trees and shrubs that support some of the basic structure of life in the tropical and subtropical regions of the earth.

\section{The role of Acacia in the production of industrial materials and products}

Gums obtained from Acacia are valuable in food and other industries due to their use as a thickening agent. Similarly, the pods of Acacia nilotica, and those of many other Acacias, which are rich in tannin are often used by tanners as an ingredient in the process of tanning animal hides into leather. The roles of gum in modern industry are diverse including keeping consistency of sauces and syrups, preventing the formation of ice crystals in frozen desserts, stabilizing the foaming in beer and thickening products (Lemenih et al., 2003). As a thickening and emulsifying agent, gum Arabic is added to a variety of products such as soft drinks, hard gummy candies, foods, cosmetics, shoe polish, pharmaceuticals, etc. As a result, it is used in thickening hand lotions, soaps, watercolor paints, and for controlling viscosity of inks. In addition, solution of gum Arabic, mixed with either potassium or ammonium dichromate, is used in photography (Lemenih et al., 2003).

\section{Types of gums and resins produced in Ethiopia}

Ethiopia produces a variety of natural gums and resins, which are broadly classified as either aromatic or nonaromatic (Table 2). Aromatic gums and resins are extracted from Acacia Commiphora species. They are hardened, resinous, exudates and obtained from certain Commiphora species and Boswellia. Ethiopia harbors diverse Commiphora species which is one of the highest in the world with 52 species of Commiphora, of which 14 species are endemic (Vollesen, 1989). The south eastern Acacia Commiphora woodlands comprises the richest diversity in the country with $35(67 \%)$ of the Commiphora species and including 9(64\%) endemic species. The major Commiphora gums of economic importance in Ethiopia are myrrh, opoponax and hagar and the names are used interchangeably to refer to the various resinous products obtained from Commiphora species (Vollesen, 1989; Kuchar, 1995).

Non-aromatic gums extracted from Acacia-Commiphora species.

They are mainly odour less and/or tasteless products that include gum Arabic. Gum Arabic is dried exudates collected from several Acacias species and sometimes known by its name 'gum Acacia. However, as to the international commercial specifications, gum Arabic as a dried exudates obtained from the stems and branches of A. Senegal and A. seyal. (FAO, 1998). In Ethiopia, the gum collected from A. Senegal and A. seyal. is also determined as gum Arabic in most reports. Good stocks of $A$. Senegal and A. seyal. are found in the western, central (Rift valley), southern and southeastern lowlands of Ethiopia (Tucker, 1986; Lemenih et al, 2003). 
Table 2. Estimated areas covered by natural gum and resin bearing species in the different regions in Ethiopia

\begin{tabular}{lcc}
\hline $\begin{array}{l}\text { Regional state } \\
\text { (hectare) }\end{array}$ & \multicolumn{1}{c}{ Genus } & Estimated area in \\
\hline Tigray & Boswellia, Sterculia, Commiphora and Acacia & 940,000 \\
Amhara & Boswellia, Commiphora, Acacia and Sterculia & 680,000 \\
Benishangul & Boswellia, Acacia and Sterculia & 100,000 \\
Gambela & Commiphora, Acacia, Sterculia & 420,000 \\
Oromia & Boswellia, Commiphora, Acacia and Sterculia & 430,000 \\
SNNP & Boswellia, Sterculia and Acacia & 70,000 \\
Somali & Boswellia, Sterculia and Acacia & 150,000 \\
Afar & Commiphora and Acacia & 65,000 \\
\hline Total & & $2,855,000$ \\
\hline
\end{tabular}

Girmay (2000).

\section{Environmental importance of Acacia wood land species}

\section{Provide habitat and food for organisms}

Due their tolerance for fire, resistance for insect pests and existence in harsh and unfavorable environmental condition, Acacias provide habitat requirements (i.e. food and cover) for different organisms including birds, mammals and numerous insect species (Jaiyeoba, 1996). This is commonly seen when variety of birds build nests on Acacia trees and depend on food sources located around the trees. An exemplary for the role of Acacia as food and habitat site is the ant and swollen-thorn Acacias symbiotic associations within Central America, South and eastern Africa. In addition, Acacia has an association with rhizobia (for fixing nitrogen) and mycorrhizal fungi (for making certain elements such as phosphorus, zinc, and copper accessible). This contributes for the development of other plants that grow beneath and/or around them. This again promotes the growth of nutritious grass and further enhances life support for animals and other organisms (LeHouerou, 1996).

\section{Climate modulation}

Acacias are gifted with the capacity to adjust microclimate of an area with their green and spreading canopies. They also promote moisture conservation by creating the required shade (LeHouerou, 1996). Acacias are also crucial in controlling desertification in arid and lowland areas (Poschen, 1986).

\section{Acacia's role in soil fertility and soil erosion control}

Acacia enhance and improve soil fertility when their parts (i.e. leaflets, flowers, pods, seeds, branches, bark pieces, and thorns are decomposed (LeHouerou, 1996). Acacias of Ethiopia play key roles in preserving the composition, structure and fertility of the soil. Due to the continued deforestation and land use changes, Acacia ecosystems are facing intense destruction. Ethiopia's Acacia forests are important in controlling soil erosion and environmental destruction, conserving water resources, preventing desertification and for restoring degraded regions (Poschen, 1986).

\section{Acacias wood land as biological nitrogen fixation}

Nitrogen is among the crucial elements in plants. It is also an essential element upon which plants and animals depend for completing their life cycles. Due to its association with both the Rhizobia and the Bradyrhizobia group of nitrogen-fixing bacteria, Acacia abyssinica is a good nitrogen fixer. Rhizobia are recognized as fast multiplying bacteria having a generation or a doubling time of 2-4h while Bradyrhizobia are characterized as slow multiplying bacteria having a generation time of 7-20h. Also Rhizobia are known for acidifying their medium of growth, while Bradyrhizobia increase the basicity of the medium in which they multiply (Lemenih and Itana, 2004). Furthermore, Rhizobia and Bradyrhizobia have different physiological adaptations, the shallower root zone being colonized more successfully by Rhizobia, while Bradyrhizobia inhabit the deeper root zone. It has been suggested that such distribution patterns of these nitrogen-fixing bacteria confer ecological advantage to the host tree and the whole rhizosphere. As producing and accessing nitrogen is expensive and requires more technology, nitrogen fixing trees should be viewed and respected as sophisticated biological industries especially in poor country such as Ethiopia, and their destruction should be perceived as the destruction of these advanced industries.

\section{Challenges of Acacia's resource conservation and utilization Bush encroachment and invasion of alien species}

Recently, bush encroachment and invasion has appeared as a great challenge affecting Acacia-Commiphora forests in Ethiopia. Invasion by bush and alien species impacts the native biodiversity and alters different ecosystem functions and ecosystems services. This has been evidenced in southern and eastern Ethiopia where Acacia- 
Commiphora widely exists in the country. The woodlands and thickets in Afar and Borana plateau are highly affected by this encroachment of bushlands. The study conducted in Borana rangeland, which is one of the main sites for Acacia forest indicated substantial increase of bushland cover from time to time. The land covered by bushland increased from 51\% in 1986 to $53.8 \%$ in 2002 and continued increasing to about $57 \%$ of the total land of the range land in 2010 (Angassa, 2007). In addition to this, alien species are major threats to desert ecosystems especially to Acacia forests in Ethiopia. Among these, prosopis juliflora has been the most notorious exotic species in the Acacia-Commiphora forests and woodlands of Ethiopia (Lemenih et al., 2008; Angassa, 2007).

\section{Demographic pressure}

Human population is rapidly increasing in the drylands of Ethiopia with an estimated natural growth rate of $2.7 \%$ (Sandford and Habtu, 2002). As population growth enhances the demand of resources for livelihood activities such as forest for fuel and income, grazing sites, farming area, it threatens the forest resources and intensifies environmental degradation (Lemenih and Kassa, 2010). In relation to this, resettlement programs carried out by initiation of oneself and by the support of government were conducted in dryland narrow-leaved deciduous forests to reduce the poverty and food insecurity of households in the degraded highland areas. Accordingly, about 440,000 household heads or 2.2 million people have been formally resettled in four regional states of Ethiopia namely, Amhara, Oromia, SNNPR (Southern Nations and Nationalities People Region), and Tigray between 2000 and 2004 alone. The demand of wood associated with resettled people for purposes like construction, fuel wood and agricultural expansion led to clearance of an estimated 1.7 million ha during the same period (Lemenih et al., 2008), causing the loss of 91,400 ha of woodlands (deciduous forests) and 76,400 ha of shrub lands annually (WBISPP, 2004).

\section{Competing land uses}

Competing land uses are the factors for loss of forest cover and biodiversity destruction in many parts of Ethiopia. In the same manner, increased demand of land for livelihood activities such as farming and livestock grazing are threatening the Acacia based ecosystems in Borena, South Ethiopia (Kamara et al., 2004; Bassi and Tache, 2007; Homann et al., 2008). In addition, enhancement of settlement linked with a change in life style, overgrazing due to the high abundance of livestock, and increased demand of wood for different purposes enhanced deforestation in parts of Borena area (Lemenih et al., 2008).

\section{Climatic variability and climate change}

According to Thornton et al. (2006), Ethiopia is among the countries more prone to climate change and with limited capacity to respond to the problem. The annual average minimum and maximum temperatures record of Ethiopia in the last 50 years indicates an increasing rate about 0.25 and $0.1^{\circ} \mathrm{C}$, respectively (INCE, 2001). Evidences of climate change and its impacts are widely apparent in Drylands of Ethiopia due to their environmental circumstance and this is also usually perceived by the local people (Deressa et al., 2008). In Ethiopia, biodiversity (flora and fauna) are climate sensitive sectors of the country (NAPA, 2007). Climate change affects the way land is used by communities and indirectly contributes for biodiversity destruction and vegetation cover loss in different aspects.

\section{Food insecurity}

Unpredictable rainfall and poor crop production are the main causes for food insecurity in Ethiopia. This results in millions to depend on food aids from different sources (Cullis, 2009). Food insecurity affects Acacia forests in that most households intensively utilize public resources such as forests and harvest wood and non-wood products for subsistence as well as to supplement family income. Food insecurity and related persistent forest destruction are threatening vast ecosystems in Drylands of Ethiopia (Hawando, 1997).

\section{Land degradation}

Land degradation refers to reduction or loss of land productivity due to the impacts on the physical, chemical or biological aspects of land. It affects environmental sustainability and efforts undertaken in poverty reduction. Although the causes for land degradation are complex, the direct and main ones are deforestation, improper cultivation and intensive livestock grazing. In Drylands where Acacia dominates the ecosystem, land degradation increases with poor governance and use of resources, notably Acacia forests and associated land. In relation to this, removal of perennial plant cover in Drylands causes rapid reduction of soil organic matter (SOM), which further induces soil erosion by water and wind, soil crusting by raindrop splash and salinization by evaporation. Particularly, vegetation clearance followed by repeated tillage that also involve crop residue burning and harvesting causes substantial reduction in SOM contents (Lemenih and Itanna, 2005; Lemenih et al., 2005). 


\section{Policy related challenges}

Agriculture is the backbone of Ethiopia's economy. As a result, there have been policies promoting of farming even at the expense of dryland forests conservation. This is evidenced when migrants supported to occupy forested lands in lowland from degraded highlands. Landlessness and shrinking farm sizes promote migration from the highlands to the lowland Drylands in Ethiopia. Government policies that support movement of people to Drylands as coping mechanism for household food insecurity and poverty in degraded highlands led to significant reduction and destruction of Acacia forest cover in lowlands (PASDEP, 2006). In relation to this, forest clearance exacerbated weak regulatory frameworks that are incapable to control open access nature lands (Lemenih et al., 2008).

Despite the availability of different environmental policies which also contains important provisions to facilitate sustainable land use, the environmental laws are not adequately implemented and lack low enforcement (EPA, 1998). Most of the policies and proclamations relevant to the Dryland resources are characterized by lack of accountable and stable institutions, weak Inter-sectoral policy integrations, lack of guideline, contradicting or conflicting contents of the strategy, etc. The aforementioned policy constrains led deciduous forests to the de facto open access for all forms of misuse. Conversion of deciduous forests to crop fields, overgrazing and excessive wood harvest for fuel wood production became a common occurrence all over the deciduous forests in Ethiopia (Lemenih et al., 2008).

\section{Conclusion and the way forward}

Deciduous forests in general and that of Acacia-Commiphora forests in particular are important natural endowments of Drylands in that they contribute to human welfare and environmental health. These forests provide socio-economic benefits such as energy source, production of home tools and protection, contribution to livestock production, income diversification through (i.e. fuel wood sell, producing charcoal and producing gum and resin), provision of medicinal values, importance in the production of industrial materials and products, etc. They also provide environmental benefits including acting as habitat and food source for organisms, role in climate modulation, improve soil fertility and erosion control and enhancing biological nitrogen fixation. Despite the growing importance of the Acacia-Commiphora narrow-leaved deciduous forests, they are under threats due to various challenges. These challenges include bush encroachment and invasion of alien species, demographic pressure, competing land uses, climatic variability and climate change, food insecurity, land degradation and police related problems.

Hence, to address the different challenges on these forests, the following ideas have been motioned as important points for better management of Acacia-Commiphora forests in Ethiopia.

a) Introducing commercial-sustainable-destocking system during droughts to reduce pressure on the forests.

b) Strengthening land tenure security and control free/open access

c) Mainstreaming natural resources management and in resettlement programs

d) Promoting on-farm and homestead tree planting/management and agro-forestry practices in arid, semiarid and dry sub-humid parts of Ethiopia

e) Practicing appropriate land use planning

f) Promoting awareness creation for stakeholders

g) Enhance cooperation among the different stake holders and adequate implementation of environmental laws

h) Incorporate indigenous ecological knowledge and their management in the protection AcaciaCommiphora forests

i) Work to develop alternative livelihood opportunities for communities who are highly dependent on forest resources

\section{References}

Angassa, A. (2007). The dynamics of savanna ecosystems and managements in Borana, southern Ethiopia. Ph.D. Thesis. Department of international Environment and Developments studies, NORAGRIC, Norwegig University of Life Sciences (UMB) As, Norway.

Bassi, M. and Tache, B. (2007). Governance and Ecosystems Management for the conservation of Biodiversity: GEM-CON-BIO Case Study Report Borana-Oromo Community Conserved Landscapes, Ethiopia. Project no: 028827. CENESTA.GEM-CON-BIO. Ethiopia.

Cullis, A. (2009).Food security in the dry lands of Ethiopia. In: Issues and Challenges in food security, pp. 5-16 (AbenetGirma and Dawit Abate, eds.). proceeding of a National Workshop Organized by the Biological Society of Ethiopia. Feb. 5-6, 2009, Faculty of Science, Addis Ababa University, Ethiopia.

Demel, T., Mulugeta L., 2005. Role of forestry in poverty alleviation in Ethiopia. Debub University, Wondo Genet College of Forestry, Shashamane, Ethiopia. 70 pp. Unpublished. 
Deressa, T., Hassan, R. and Ringler, C. (2008). Measuring Ethiopian farmers' vulnerability to climate change across regional states. IFPRI Discussion paper 00806, IFPRI (International Food Policy Research Institute). Washington, D.C.

EPA (1998). Environmental Protection Authority, National action plan to combat desertification. Environmental Protection Authority, Federal Democratic Republic of Ethiopia. Addis Ababa.

FAO (1998). Rome declaration on world food security and world food summit of action. http//www. fao.org/docerp/003/w3613e/w3613e00.htm. FAO.

FAO (2005). State of the world's forests.Deforestation Rate in Ethiopia, FAO, Rome.

Farah, A.Y. (1994). The milk of Boswellia forests: frankincense production among the pastoral Somali, Tia RittaHjort of Ornaas (ed.). Uppsala University, Sweden.

GIRMAY, F., 2000. The status of gum arabic and resins in Ethiopia. Report of the Meeting of the Network for Natural Gum and Resins in Africa (NGARA) 29th-31st May, Nairobi, Kenya. pp. 14-22.

Hawando, Y. (1997). Desertification in Ethiopian highlands. RALA Report No. 200. Norwegian Church AID, Addis Ababa, Ethiopia, 162 pp.

Homann, S., Rischkowsky, B. and Steinbach, J. (2008).The effect of development interventions on the use of indigenous range Management Strategies in the Borana Lowlands in Ethiopia. Land Degrad. Develop. 19: 368-387.

INCE (2001). Initial National Communication of Ethiopia to the United Nations Framework Convention on Climate Change (UNFCCC).Federal Democratic Republic of Ethiopia, Ministry of Water Resources, National Meteorological Services Agency. Addis Ababa.

Jaiyeoba, I.A. (1996). Amelioration of soil fertility by woody perennials in cropping fields: evaluation of three tree species in the semi-arid zone of Nigeria. Journal of Arid Environments 33:473-482.

Kamara, A.B., Swallow, B., and Kirk, M. (2004). Policies, interventions and institutional change in pastoral resource management in Borana, Southern Ethiopia. Development policy Review 22: 381-403.

Kuchar, P. (1995). The Plants of Somalia: An Overview and Checklist. Revised Draft, LBll-USAID, CRDP, Mogadishu, $329 \mathrm{pp}$

Kuchar, P. (1998). Identification and characterization of Burseraceae in the Southeastern Ethiopia. Southeastern Rangelands Project Technical Paper, Addis Ababa, Ethiopia.

LeHouerou, H.N. (1996). Climate change, drought and desertification: review. Journal of Arid Environments 34:133-185.

Lemenih M, Tolera M, Karltun E (2008). Deforestation: impact on soil quality, biodiversity and livelihoods in the highlands of Ethiopia. In: Sanchez IB, Alonso CL (eds) Deforestation research progress. Nova Science, New York, pp 21-39.

Lemenih, M. and Itana, F. (2004). Soil carbon stocks under various vegetation types and its dynamics following deforestation and conversion to arable lands along an elevation gradient in southern Ethiopia. Geoderma123:177-188.

Lemenih, M. and Itanna, F. (2005). Soil carbon stocks under various vegetation types and its dynamics following deforestation and conversion to arable lands along an elevation gradient in Southern Ethiopia. Geoderma 123: 177-188.

Lemenih, M. and Kassa, H. (2008). Management guidelines for Boswellia papyrifera and its frankincense in Ethiopia. Center for International Forestry Research- Ethiopia, Addis Ababa, Ethiopia.

Lemenih, M. and Woldemariam, T. (2010). Review of forest, woodland and bushland resources in Ethiopia up to 2008. In: Ethiopia Environment Review, pp. 131-186 (Edwards, S., ed.). Forum for Environment. Addis Ababa, Ethiopia.

Lemenih, M., Abebe, T. and Olsson, M. (2003). Gum and resin resources from some Acacia, Boswellia and Commiphora species and their economic contribution in Liban, Southeastern Ethiopia. Journal of Arid Environments 55: 465-482.

Lemenih, M., Karltun, E. and Olsson, M. (2005). Assessing soil chemical and physical property responses to deforestation and subsequent cultivation in small holders farming system in Ethiopia. Agriculture, Ecosystem and Environment 105: 373-386.

Lemenih, M., Kassa, H. (2010). Socio-economic and environmental significance of dry land resources of Ethiopia and their development challenges. Journal of Agriculture and Development 1 (1): 71-91.

Lemenih, M.and Teketay, D. (2003). Frankincense and myrrh resources of Ethiopia. II. Medicinal and industrial uses. Ethiopia Journal of Science, SINET26:161-172.

NAPA (2007). National Adaptation Programme of Action of Ethiopia, The Federal Democratic Republic of Ethiopia, Ministry of Water Resources and National Meteorological Agency, Addis Ababa, Ethiopia.

PASDEP (2006). Plan for Accelerated and Sustainable Development in Ethiopia, Plan for Accelerated and Sustainable Development in Ethiopia. Ministry of Finance and Economic Development, Addis Ababa, Ethiopia. 
Poschen, P. (1986). An evaluation of the Acacia albida based agro forestry practices in the Hararge Highlands of eastern Ethiopia. Agroforestry System 4:129-143.

Sandford, S. and Habtu, Y. (2002). Emergency response interventions in pastoral areas of Ethiopia. Department for International Development (DFID). London, UK.

Thornton, P.K., Jones, P.G., Owiyo, T., Kruska, R.L., Herrero, M., Kristjanson, P., Noten-baert, A., Bekele, N. and Omolo, A. (2006). Mapping climate vulnerability and poverty in Africa. Report to the Department for International Development, ILRI, Nairobi, Kenya.

Thulin, M. and Claeson, P. (1991). The botanical origin of scented myrrh (Bissabolor Habak Hadi). Economic Botany 45(4): 487-494.

Tucker, A. O. (1986). Frankincense and Myrrh. Economic Botany, 40(4), 1986, pp. 425-433

Vollesen, K. (1989). Burseraceae. In: Flora of Ethiopia, Volume 3, pp. 442-478, (Hedberg, I. and Edwards, S., eds). National Herbarium, Addis Ababa University, Addis Abeba and Uppsala University, Uppsala.

WBISPP (2004). Woody Biomass Inventory and Strategic Planning Project, Forest Resources of Ethiopia. Addis Ababa, Ethiopia.

Worku, A. (2006). Population status and socio-economic importance of Gum and Resin Bearing species in Borana Lowlands, southern Ethiopia. Ethiopia. MSc thesis, Addis Ababa University, Biology Department, Addis Ababa, Ethiopia. 